\title{
Do you know this syndrome?
}

\author{
Você conhece esta síndrome?
}

\section{Gabriela Maria Abreu Gontijo}

\section{CASE REPORT}

The case of a 13-year-old female patient is here described. Frontal and temporal lesions appeared at 4 years of age, followed by smaller malar and chin lesions since age 5 . Her mother referred hypochromic maculae on dorsum present from birth. In childhood, she had one episode of seizure associated with fever, with normal EEG. There was no family history of similar skin lesions.

In CT of the skull, multiple amorphous subependimary calcifications were present. In thoracic and lumbar spine $\mathrm{CT}$, partial defect in fusion of the posterior neural arch was found at the T11, T12, S1 and L5 levels.

On examination, she had multiple pinkishbrown, shiny papules, about $2 \mathrm{~mm}$ in diameter in the malar region and chin, brownish frontal and preauricular plaques and multiple hypochromic stains on the trunk, including ash leaf spots (Figures 1, 2 and 3). The frontal and pre-auricular lesions are probably fibrous plaques, classified as angiofibromas; the

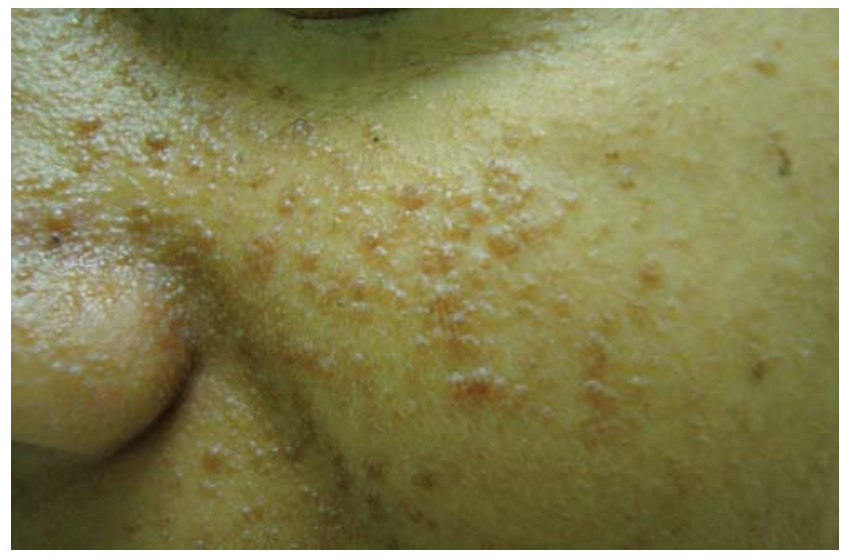

FIGURE 1: Multiple pinkish-brown shiny papules, about $2 \mathrm{~mm}$ in diameter in the malar region patient did not allow a biopsy, so other possible diagnosis such as melanocytic naevi, verrucous naevi and even Shagreen patch with unusual localization should be considered.

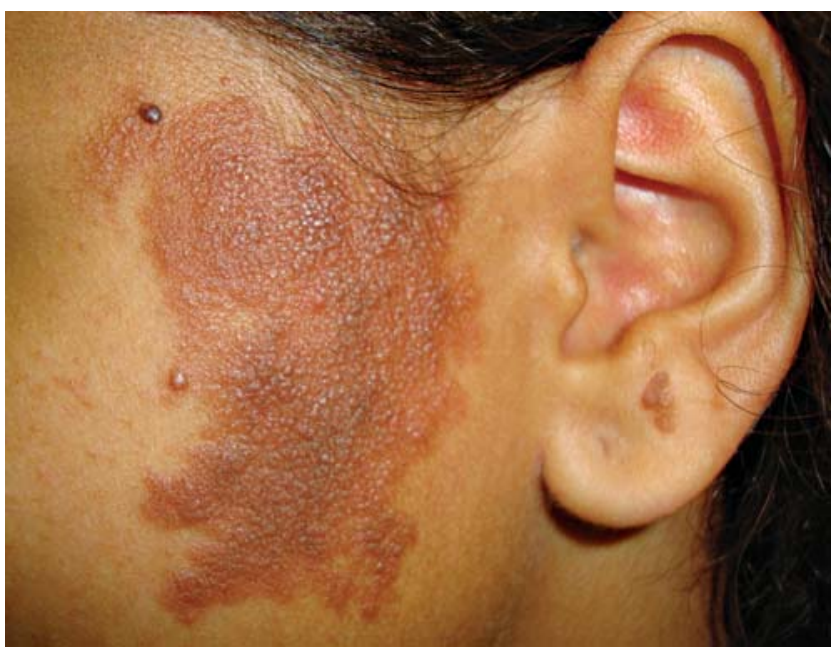

FIGURE 2: Brownish pre-auricular plaque

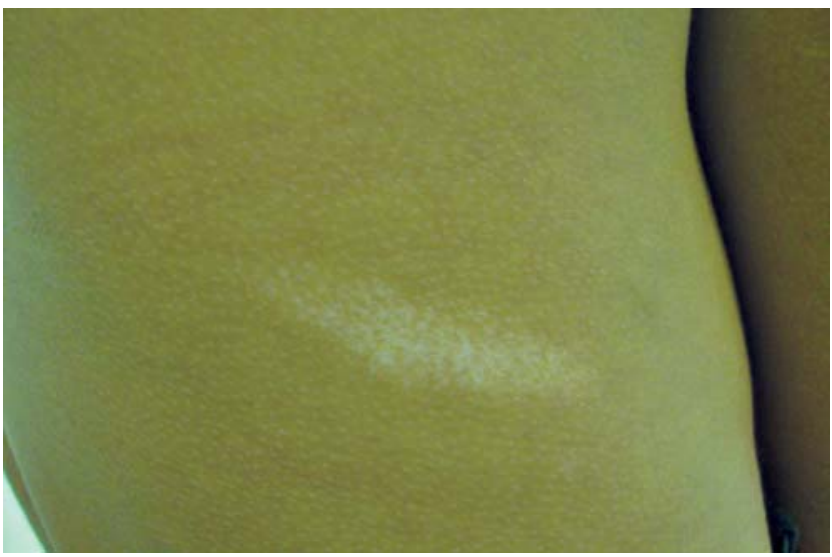

Figure 3: Ash leaf spot

Received on 23.02.2012

Approved by the Advisory Board and accepted for publication on 31.05.2012

* Study carried out at a Private Clinic - Belo Horizonte (MG), Brazil

Financial Support: None.

Conflict of Interests: None.

1 MD, Dermatologist - Private Clinic - Belo Horizonte (MG), Brazil.

@2013 by Anais Brasileiros de Dermatologia 


\section{DISCUSSION}

The Bourneville-Pringle syndrome (Tuberous Sclerosis) is an autosomal dominant neurocutaneous disorder. Two thirds of cases are caused by sporadic mutations; the incidence is 1:6800-10000 people. ${ }^{1,2}$ It is characterized by the development of multiple hamartomas in various systems, especially brain, skin, retina, kidney, heart and lung. ${ }^{1}$

Two tumor suppressor genes are responsible for the syndrome, TSC1 and TSC2, which encode the hamartin and tuberin proteins. ${ }^{1,23,4}$ The hamartin/tuberin complex is an important inhibitor of tumor growth; its absence triggers the loss of proliferation and cell migration inhibition. ${ }^{4}$

As diagnosis is mainly based on clinical criteria, it may be particularly difficult early in life, since many stigmas become apparent only in late childhood or adulthood.

The consensus of Tuberous Sclerosis Complex defines that the presence of two major criteria or one major and two minor criteria establish the definitive diagnosis of the syndrome. ${ }^{3}$ The major features are: ${ }^{1,3}$

- Facial angiofibromas or forehead plaque

- Nontraumatic ungual or periungual fibroma

- Hypomelanotic macule

- Shagreen patch

- Multiple retinal nodular hamartomas

- Cortical tuber

- Subependymal nodule

- Subependymal giant cell astrocytoma

- Cardiac rhabdomyoma

- Lymphangiomyomatosis

- Renal angiomyolipoma

Minor features are:

- Multiple, randomly distributed pits in dental enamel

- Hamartomatous rectal polyps

- Bone cysts

- Cerebral white matter radial migration lines

- Gingival fibromas

- Nonrenal hamartomas

- Retinal achromic patch

- "Confetti" skin lesions

- Multiple renal cysts
The most important skin lesions are: ${ }^{1,5}$

- Hypomelanotic maculae: the earliest cutaneous lesions, present at birth or infancy. The most characteristic hypochromic spots are those which have the form of leaves, called "ash-leaf spots". ${ }^{4}$

- Facial angiofibromas: apparent between the second and fifth year of life. Can be treated by cryosurgery, dermabrasion, curettage, peelings, laser or high radiofrequency. ${ }^{6}$ Recent studies described good results with topical rapamycin, that was also efficient in the treatment of hypomelanotic maculae. ${ }^{7,8}$

- Shagreen patches: yellowish or erythematous plaques on dorsal body surface, which are connective tissue nevi.

- Forehead fibrous plaques: yellowish-brown, located on the forehead or scalp. They appear at any age and may be seen at birth.

- Periungual fibromas

- "Confetti-like" macules

Patients also have other manifestations such as dental pits, retinal hamartomas, renal angiomyolipoma, cardiac rhabdomyomas, cerebral hamartomas, epilepsy, and cognitive impairment. ${ }^{1.2}$

The diagnosis should be made as early as possible so that the associated complications may be evaluated and treated. 


\begin{abstract}
The Bourneville-Pringle syndrome is an autosomal dominant neurocutaneous disorder characterized by the development of multiple hamartomas in various systems, especially brain, skin, retina, kidney, heart and lung. The case of a patient with brownish plaques on the forehead and temporal region, pink malar and chin papules, and hypopigmented macules on the back and trunk is described. The diagnosis of the BournevillePringle syndrome is based on clinical criteria. Presence of two major criteria, such as facial angiofibromas, forehead fibrous plaques, three or more hypomelanotic macules establish the definitive diagnosis. The diagnosis should be made as early as possible in order to assess and treat the associated complications.

Keywords: Angiofibroma; Hamartoma; Tuberous sclerosis

Resumo: A Síndrome de Bourneville-Pringle é desordem neurocutânea autossômica dominante caracterizada pelo desenvolvimento de hamartomas múltiplos em vários locais do corpo, especialmente cérebro, pele, retina, rim, coração e pulmão. Descreve-se caso de paciente com placas acastanhadas na fronte e região temporal, pápulas róseas na região malar e mento e máculas hipocrômicas no dorso e tronco. O diagnóstico da síndrome Bourneville-Pringle é baseado em critérios clínicos. Presença de dois critérios maiores, como angiofibromas faciais, placas fibrosas frontais e 3 ou mais máculas hipomelanóticas estabelecem o diagnóstico definitivo. Devese fazer o diagnóstico o mais precocemente possível para que as complicações associadas sejam avaliadas e tratadas.

Palavras-chave: Angiofibroma; Esclerose tuberosa; Hamartoma
\end{abstract}

\title{
REFERENCES
}

1. Schwartz RA, Fernandez G, Kotulska K, Józwiak S. Tuberous sclerosis complex: advances in diagnosis, genetics, and management. J Am Acad Dermatol. 2007;57:189-202.

2. Borkowska J, Schwartz RA, Kotulska K, Jozwiak S. Tuberous sclerosis complex: tumors and tumorigenesis. Int J Dermatol. 2011;50:13-20.

3. Curatolo P, Bombardieri R, Jozwiak S. Tuberous sclerosis. Lancet 2008;372:65768.

4. Rodrigues DA, Gomes CM, Costa IMC. Esclerose tuberosa. An Bras Dermatol. 2012;87:185-97.

5. Fernández-Guarino M, Boixeda P, Anaya MJ, Beldar P, Jaén P. Clinical Findings in 67 Patients With Tuberous Sclerosis. Actas Dermosifiliogr. 2009;100:596-601.

6. Gomes AAR, Gomes YVR, Lima FB, Pessoa SGP. Multiple facial angiofibromas treated with high-frequency equipment. An Bras Dermatol. 2011;86:S186-9.

7. DeKlotz CMC, Ogram AE, Singh S, Dronavalli S, MacGragor JL. Dramatic improvement of facial angiofibromas in tuberous sclerosis with topical rapamycin: optimizin a treatment protocol. Arch Dermatol. 2011;147:1116-7.

8. Wataya-Kaneda M, Tanaka M, Nakamura A, Matsumoto S, Katayama I. A novel application of topical rapamycin formulation, an inhibitor of mTOR, for patients with hypomelanotic macules in tuberous sclerosis complex. Arch Dermatol.

MAILING ADDRESS:

Gabriela Maria Abreu Gontijo

Rua João Antônio Cardoso, 152 - Ouro Preto

31310-390. Belo Horizonte, MG.

Brazil 2012;148:138-9

E-mail: gabrielagontijo@hotmail.com

How to cite this article: Gontijo GMA. Do you know this syndrome? Bourneville-Pringle syndrome, a neurocutaneous disorder. An Bras Dermatol. 2013;88(2):303-5 